\author{
MICHAŁ ŁUCZYŃSKI \\ Uniwersytet Jagielloński
}

\title{
JESZCZE O PRAPOLSKIM ETNONIMIE POLANIE
}

Zagadnienie etnonimii słowiańskiej od dziesięcioleci wywołuje gorące spory i dyskusje naukowców różnych dziedzin. Jednym z etnonimów, który stał się ostatnio przedmiotem licznych kontrowersji, jest wymieniona w tytule nazwa Polanie, której poświęcony został niniejszy przyczynek.

Dyskusję wywołał, zakwestionowawszy autentyczność tej nazwy etnicznej, a zarazem podważając istnienie ,plemienia Polan”, których nazwa miałaby dać początek nazwom typu Polska, Polak itd., prof. Przemysław Urbańczyk (Urbańczyk 2008: 317), co wywołało krytyczne głosy tak w środowisku językoznawców (Mańczak 2010; por. Tomala 2011), jak historyków (Labuda 2008). Stanowisko tego autora wkrótce wsparł jednak László Tapolcai (2009; 2010; por. omówienie jego poglądów przez: Bagi 2012). Następnie P. Urbańczyk jeszcze raz potwierdził swoje stanowisko w głośnej książce o Mieszku I (Urbańczyk 2012: 111-112), a następnie spopularyzował w kilku wypowiedziach o charakterze publicystycznym (np. Bajer 2013). Ponieważ dyskusja nad istnieniem bądź nieistnieniem plemienia prapolskich Polan, a tym samym - autentycznością lub nie etnonimu Polanie, nie została jednoznacznie rozstrzygnięta, a P. Urbańczyk podniósł pewne istotne kwestie, które jak się wydaje, nie zostały należycie podjęte, problem tytułowego etnonimu wydaje się być kwestią otwartą, która niewątpliwie domaga się ponownej analizy.

Przede wszystkim - twierdzi P. Urbańczyk - tezę o nieistnieniu Polan jako jednostki plemiennej wspierać ma to, iż „w tekstach źródłowych nie pojawiają się [oni] przed rokiem 1000" (Urbańczyk 2008). Jest to nieścisłość, którą należy wyjaśnić, weryfikując podstawy poglądów autora „Mieszka Pierwszego Tajemniczego". Pierwsze ze źródeł wymieniających etnonim Poloni, czyli Vita s. Adalberti, tzw. Żywot I Kanapariusza, jest datowane na ok. 998-999 rok, a dotyczy wydarzeń z lat 995-997, wiadomości w nim zawarte pochodzą więc bezsprzecznie sprzed zjazdu gnieźnieńskiego. Znajdujemy w nim wzmiankę: Bolizlav Polanorum duce 'Bolesław książę Polan'. Wyraz w formie zależnej Polanorum to formacja ewidentnie deetnonimiczna: Polaniorum $=$ Poloniorum, od Poloni z łac. sufiksem -orum, dosł. 'polański'. Jego odpowiednikiem ppol. był najpewniej etnonimu Polanie $>$ psł. *Poljaninъ sg, *Poljaně pl. 'mieszkańcy pól'. Epitet Chrobrego tłumaczył najpewniej określe- 
nie *polanbsk 'polański'. Łacińska fraza Bolizlav Polanorum duce mogła być więc próbą przekładu tytulatury typu ppol. *Bolěslavb *polanbsk *kъnzb lub podobnej. Do zakresu semantycznego tego epitetu wrócimy w dalszym ciągu rozważań. Drugą kwestią, którą należy na wstępie wyjaśnić, jest niezasadność kwestionowania wiarygodności tzw. Latopisu Nestora z XII wieku (Powieści minionych lat, w skrócie PVL), podającej szczegółowe informacje o plemieniu srus. Poljanie, niewątpliwie pochodzące z autopsji, na co zwraca uwagę szereg autorów. Jak można sądzić, źródło łacińskie odnosi się do Polan zamieszkujących bliżej nieokreślone terytoria na terenie późniejszej Polski, staroruskie - do Polan zasiedlających Naddnieprze i okolice Kijowa. Interesujący tu nas etnonim został zatem potwierdzony niezależnie przez dwa źródła historyczne i podważanie ich wiarygodności nie wydaje się uzasadnione. Niezależne poświadczenie tych nazw i ich niewątpliwy autentyzm świadczą o istnieniu odpowiedniego etnosu/odpowiednich etnosów określanych za ich pomocą. Pozwala to zakwestionować główną tezę P. Urbańczyka o pseudoetnonimie Polanie, a także podobnie krytyczny stosunek tego badacza do etnonimu Wiślanie (łac. Uuislane), poświadczonego przez II część tzw. Geografa bawarskiego z początku X wieku. Podważanie wiarygodności tekstów źródłowych należy w tym wypadku ocenić jako pozbawione podstaw, a próbę sklasyfikowania staroruskiego etnonimu jako pseudoetnonimu pochodzenia literackiego - za nieprzekonującą.

Przypominając o zjawisku nadawania wtórnych nazw mieszkańców kontynuujących nie nazwy plemienne, lecz utworzonych od nazw geograficznych, krain lub okręgów grodowych, P. Urbańczyk pisze:

Równie mylące jest pozorne potwierdzenie w Powieści minionych lat funkcjonowania nazwy „plemienia” Polan, co miałoby odpowiadać [...] zjawisku podwójnego, a nawet wielokrotnego występowania nazw etnicznych na różnych, często odległych od siebie, obszarach [...]. Istnienia Polan nie potwierdza jednak żadne źródło z pierwszego tysiąclecia.

I dalej:

Opierając się na faktach źródłowych, należy założyć, że pseudoetnonim Poloni/Palani/Poleni pojawił się dopiero na początku XI wieku w szeregu dokumentów związanych z przyjmowaniem ogólnej nazwy politycznej przez wieloetniczne państwo Bolesława Chrobrego [...]. W tych tekstach (...) Poloni/Palani/Poleni nie oznaczają jakiegoś starożytnego „plemienia”, lecz aktualnych poddanych konkretnego władcy, czy może raczej gens Polonorum, czyli jego najbliższe otoczenie polityczne [podkreślenie moje - M.Ł.]. Ten niuans nie był zapewne oczywisty dla zewnętrznych obserwatorów Europy środkowo-wschodniej, którzy, tak jak kompilator Powieści, operowali biblijnym schematem wyłaniania się państw z jakichś wcześniejszych struktur etnicznych (Urbańczyk 2012: 111).

Zdecydowano się na przytoczenie w tym krótkim artykule obszernych fragmentów pracy P. Urbańczyka, aby na potrzeby analizy tym wyraźniej wyłożyć poglądy tego autora na omawianą kwestię.

Po pierwsze zjawisko podwójnych (a nawet potrójnych) etnonimów słowiańskich nie jest zjawiskiem niespotykanym. Według większości historyków świadczy ono o migracjach i podziałach plemiennych, nie zaś o niezależnym powstawaniu identycznych nazw w różnych rejonach Słowiańszczyzny. Należą do nich m.in. Drewlanie, Chorwaci, Serbowie, Dulębowie, których źródła historyczne lokalizują zarówno w na obszarze wschodnio-, jak 
i zachodnio- i południowosłowiańskim. Jak wiemy, wędrówki takie zostały wszechstronnie oświetlone przez źródła pisane (saskie, greckie itd.), a np. wśród nadadriatyckich Chorwatów trwała była pamięć o ich nadwiślańskiej ojczyźnie. Wschodnio- i zachodniosłowiańscy Polanie nie byliby więc na mapie plemiennej Słowiańszczyzny ewenementem. Wiadomo natomiast, że nazwa ta powtarza się nie tylko w Polsce i pod Kijowem, lecz także w Macedonii (Rymut 1967: 211). Etnonimowi Polanie można więc przypisać zasięg ogólnosłowiański. Nie ma podstawy pogląd, iż ta nazwa „nie istniała”, a jest tylko wymysłem kronikarzy.

Kolejna kwestia wiąże się z koncepcją zapożyczenia przez Ruś kijowską owego „pseudoetnonimu” jako jednej z „prestiżowych” nazw przez ruską tradycję dynastyczną i włączenie go do tamtejszej tradycji państwotwórczej. Wiadomo, że część wiadomości politycznych Nestora pochodziła z początku XII wieku i odnosiła się do realiów piastowskiej Polski (np. etnonimy Pomorzanie, Mazowszanie późniejszego pochodzenia, uznanie Luciców za plemię „lackie” itd.). Nie usprawiedliwia to jednak uznania wszystkich danych latopisu za późniejszy wtręt, o czym świadczy szczegółowy zarys rozmieszczenia plemion wschodniosłowiańskich i pogranicznych w dorzeczu Dniepru, Bugu i Suły, zawarty w PVL.

Po drugie kontrowersyjne wydają się zabiegi chronologizacyjne autora Trudnych początków Polski. Jak już wspomniano wyżej, przyjmowana najczęściej data powstania $\dot{Z} y$ wotu Kanapariusza, zawierającego derywat od łac. ${ }^{* * P o l o n i}$ (ściśle ${ }^{* * P o l a n i}$, z typową dla grafii łacińskiej oscylacją samogłoskową $o \leftrightarrow a$ ) to okres przed rokiem 1000. Nie ma więc potrzeby prostowania tego nieporozumienia po raz kolejny.

Po trzecie bezpodstawny jest pogląd, jakoby tworzyła PVL, opisując historię plemienia Polan, wzorowała się na schemacie biblijnym i tworzyła historię ex post. Przeciwnie, liczne szczegóły świadczą o relacji z pierwszej ręki jako źródle wiedzy kronikarza. Należą tu uwagi typowo etnograficzne, obyczajowe na temat ostatnich Polan mieszkających w Kijowie, od których autor albo jego informator mógł zasięgnąc informacji na ten temat. Staroruska kronika rejestruje etnonimy o rozmaitej genezie i chronologii. Oprócz tych prasłowiańskich (Dulębowie, Chorwaci, Krywicze, Ulicze itd.) przekazuje też wtórne etnonimy (lub raczej socjonimy) odtoponimiczne (Pomorzanie, Mazowszanie). Podkreślenie, iż Lucicy należą do plemion „lackich” dowodzi, iż autor (kompilator) był dobrze poinformowany o realiach politycznych i przejściowych zdobyczach książąt polskich w dobie rozbicia dzielnicowego. Przemawia to więc niezbicie za wiarygodnością informacji podawanych przez PVL.

Hipotezę P. Urbańczyka w wymienionych punktach należy więc odrzucić. Na uwagę zasługują jednak niewątpliwie jego uwagi dotyczące niektórych innych kwestii. Oto one:

1) teoria o Polanach wielkopolskich (kujawskich) funkcjonująca w historiografii na zasadzie dowiedzionego faktu historycznego;

2) nieendoetnonimiczny charakter określenia Polanie obejmującego ogół poddanych Bolesława Chrobrego;

3) problem dublowania się etnonimów i ich wzajemnych relacji.

Ad. 1

Podzielane przez P. Urbańczyka krytyczne stanowisko Andrzeja Buko w sprawie Polan można w zasadzie zaakceptować, z tym jednak zastrzeżeniem, iż Polanie jako „konstrukt historyków" dotyczy wyłącznie Polan wielkopolskich (kujawskich). W rzeczywistości nic 
nie przemawia za tym, aby Polanie zamieszkiwali kiedykolwiek Wielkopolskę. P. Urbańczyk ma niewątpliwie rację, pisząc o ,problemie niewidocznych źródłowo Polan” i ich rzekomym udziale w budowaniu zrębów państwa wczesnopiastowskiego. Nie można jednak zgodzić się z tym autorem w wykreślaniu Polan z mapy wczesnośredniowiecznej Polski w ogóle. W tym względzie P. Urbańczyk, wydaje się, w swej krytyce idzie zdecydowanie za daleko.

Jego polemika z Gerardem Labudą zasługuje niewątpliwie na uwagę, mimo że jak dotąd nie wzbudziła należytej refleksji w piśmiennictwie naukowym. Broniąc tradycyjnej historycznej wykładni, G. Labuda (2008: 230) podsumowuje swoje stanowisko:

[Polska] wyszła z opłotków plemiennej struktury Polan, jako rdzenia państwa, piastowskiego, na arenę ogólnopolską, wciągając w nowo utworzoną ponadplemienną strukturę państwową Pomorze, Mazowsze, ziemie Wiślan [...].

P. Urbańczyk słusznie podkreśla brak podstawy źródłowej do przypisywania Polanom wybitnej roli w jednoczeniu Wielkopolski wokół Gniezna, ani nawet do lokalizowania ich w północno-zachodniej Polsce. Nieprzekonująco jednak odmawia „Polanom” prawa do egzystencji na mapie wczesnośredniowiecznej Polski, wbrew wymowie źródeł historycznych.

\section{Ad. 2}

P. Urbańczyk trafnie zauważa, że określanie poddanych Chrobrego mianem Polan, a jego państwa jako Polonii (Polski) upowszechnia się dzięki zachodnioeuropejskim źródłom pisanym i nasila się $\mathrm{w}$ pierwszych latach XI wieku w środowiskach niemieckim i czeskim. Stanowi to wyraźną wskazówkę co do możliwej literackiej genezy choronimu w znaczeniu bliskim współczesnemu (Polska jako 'kraj pól', ze zbliżonym do współczesnego zasięgiem geograficznym itd.). Trudno natomiast zgodzić się z hipotezą o nazwaniu w ten sposób kraju i poddanych Chrobrego przez cudzoziemców. Nawet jeśli na ewentualny rozwój semantyczny choronimu i etnonimu wpływ mieli obcokrajowcy, nic nie usprawiedliwia stanowiska, iż terminy te nie miały pierwowzorów w historycznym nazewnictwie plemiennym lub geograficznym.

Ad. 3

Wydaje się, iż problem genezy podwójnego (a nawet potrójnego, jak wskazano powyżej) etnonimu Polanie został przez P. Urbańczyka rozwiązany niewłaściwie. W argumentacji Autora widoczne jest podejście niehistoryczne. Pisze on: „Jeżeli tak było [tzn. jeżeli prapolskie określenie zbiorcze Polanie pochodziło od ap. pole, a nie od starożytnego plemienia Polan, a więc było jedna z sekundarnych nazw mieszkańców - przyp. M.Ł.], to częste w polskiej historiografii przytaczanie zapisów XII-wiecznej kroniki ruskiej jako dowodu istnienia jakichś Polan w czasach przedmieszkowych trzeba uznać za konstruowanie fałszywej dokumentacji. W tym rozumowaniu bowiem brak źródłowego potwierdzenia istnienia polskich Polan w IX i X wieku kompensuje się odwołaniem do późnego źródła ruskiego, które zarejestrowało tradycje ukształtowane zapewne pod wpływem wiadomości napływających z Polski dopiero w XI wieku” (Urbańczyk 2012: 112).

Wnioskowanie o zajściu tu wyłącznie nazewniczej pożyczki staropolsko-staroruskiej na podstawie arbitralnego odrzucenia PVL i Vita s. Adalberti nie wydaje metodycznie właści- 
we. Geneza zdublowania nazwy wiązała się najpewniej z przeniesieniem etnonimu motywowanym przez migrację ludności, podobnie jak w wypadku np. Chorwatów czy Serbów. Przypuszczenie takie uzasadnia zresztą samo źródło staroruskie, odrzucanie jego świadectwa i poprawianie go wydaje się więc sprzeczne z zasadami krytyki historycznej.

Podsumowując tę część artykułu, zarówno lokalizacja hipotetycznych Polan na terenie Polski, jak i typ etnonimiczny samej nazwy oraz relacja między zdublowanymi etnonimami pozostają niejasne. P. Urbańczykowi jako zasługę należy poczytać zwrócenie uwagi na niektóre problemy wiążące się z badaniami nad ww. nazwą etniczną i ich wyraźne wyartykułowanie. Z częścią poglądów tego badacza trudno się jednak zgodzić (jak np. ze zdezauwowaniem wartości pierwszych poświadczeń nazwy i oraz interpretacją samych etnonimów). Wydaje się, iż próbę rozwiązania tego problemu należy rozpocząć od przywołania dotychczasowego stanu badań nad etnonimią prapolską, by następnie zweryfikować stan podstawy źródłowej oraz właściwie zinterpretować pierwsze zapisy.

Przede wszystkim należy podkreślić, że w świetle tzw. Geografa bawarskiego (z ok. 845 roku) zarówno $P V L$, jak i Vita s. Adalberti i pozostałe przekazy zawierają wiarygodne informacje pozwalające rozwiązać problem etnonimu Polanie. Zgodnie z aktualnym stanem badań nad tzw. zapiską karolińską, plemienną mapę Polski można by zrekonstruować w następującej postaci: w X wieku Wielkopolskę zamieszkiwali Głobianie (400 grodów), oraz kilka pomniejszych plemion, jak Pyrzyczanie, Brzeżanie, Lubuszanie, „Miloxi” i wzmiankowani przez Widukinda Lic(z)(i)kowicy (łac. Licicaviki); Śląsk: Dziadoszanie, Bobrzanie, Trzebowianie, Ślężanie i Opolanie, a także pomniejsze plemiona czeskie (Gołęszyce i Głupogłowy); natomiast Małopolskę: Lędzanie-Lędzicy (98 grodów) oraz Wiślanie. Ci ostatni zajmowali, jak się przypuszcza, zachodnią Małopolskę (ziemię krakowską), Lędzanie zaś - Małopolskę wschodnią (okolice Chełma, Przemyśla, Sanoka, Zamojszczyznę, Sandomierszczyznę i Lubelszczyznę) oraz część Wołynia. Tymczasem według wyraźnego świadectwa PVL Polanie byli odłamem Lędzan, którzy pierwotnie zamieszkiwali rejon Dunaju, a następnie wskutek najazdu „Wołochów” (tzn. najpewniej Rumunów) zostali wyparci w kierunku Naddnieprza (grupa wschodnia) oraz Wisły (grupa zachodnia). Nie widać więc obiektywnych przesłanek, by uważać zachodnich Polan za plemię wielkopolskie (kujawskie), jak niemal powszechnie przyjmuje historiografia. Zgodnie z wyraźnym świadectwem tekstu źródłowego Polanie powinni być lokalizowani w Małopolsce, tym bardziej że - w świetle analizy źródeł historycznych - właśnie w związku z Małopolską wspominani są w najwcześniejszych źródłach dotyczących ich zachodniosłowiańskiego odłamu.

Jak już wspomniano wyżej, Żywot I Kanapariusza (ok. 998) w kontekście wydarzeń z 995 roku określa Bolesława Chrobrego jako księcia Polan (łac. Polanorum duce). Tymczasem Chrobry, jako siostrzeniec księcia Bolesława II, pod zwierzchnictwem czeskim zarządzał Krakowem i podległymi mu pertynencjami (łac. civitas Craccoa z Dokumentu praskiego) aż do 992/993 roku, gdy śmierci Mieszka I najechał państwo gnieźnieńskie i scalił obydwa civitas w jeden organizm państwowy, od 1002/1003 roku określany w źródłach łacińskich jako Polonia, Polenia, Polania itd. Pierwotnie jednak zakres semantyczny tej nazwy prawdopodobnie nie obejmował całego terytorium państwa, jak o tym świadczy chociażby analiza odpowiednich fragmentów żywotów św. Wojciecha. 
Należy zauważyć, iż epitet Chrobrego Polanorum (tj. najpewniej ppol. *polanbsk) wyraźnie wskazuje, iż panował on nad plemieniem Polan w sensie przede wszystkim militarnym. Analogicznie Mieszko (łac. Misaca) określony został przez Widukinda jako rex Licicavicorum, a więc jak się uważa współcześnie 'wódz Lic(z)ykowców', zapewne małego plemienia w Wielkopolsce lub na zachodnim Pomorzu. Niewielkie to plemię (albo ród) próbowano lokalizować w dorzeczu Warty i Odry. Nomenklatura wskazuje na geograficzny aspekt tego typu tytulatury i pozwala szukać genezy przydomku Chrobrego w 'krainie Polan', gdzie by na trwałe do niego przylgnął i stał się na tyle stałym epitetem, że funkcjonował nawet to podbiciu sąsiednich terenów. Skądinąd wiadomo, że przed 992 rokiem Chrobry przez blisko dekadę zarządzał Krakowem, a dzielnicą, gdzie mógłby nabyć taki tytuł, była najprawdopodobniej właśnie Małopolska zachodnia.

Z kolei Vita Quinque Fratrum Brunona, z lat 1006-1008, opisując wędrówkę eremitów Benedykta i Jana, odnotowuje provintiam Polanorum jako 'ziemie Polan', do których droga wiedzie z Węgier przez „Alpy” (tzn. Tatry Wysokie; rekonstruowany szlak św. Wojciecha i jego następców wiódł najpewniej z Węgier przez Ostrzyhom, doliny rzek na Słowacji, przełęcze w Karpatach i dolinę Popradu, Dunajec aż do Krakowa). Według hagiografa po przebyciu długiej i powikłanej drogi bracia mieli wstąpić na ziemie „Polan nieznanego języka". Źródło notuje nazwę w formie Polanorum, według G. Labudy (2008) w postaci jeszcze nie do końca zlatynizowanej, a więc zapewne wprost z autopsji (śr.-łac. nazwę substytucyjną Polonia, z harmonizacją wokaliczną, podają dopiero późniejsze źródła, a wariant ten utrwaliła dopiero m.in. Kronika Galla Anonima z ok. 1113 roku; Thietmar, ok. 1018 roku, ma jeszcze formę Polenia, Poleni, wykazującą wpływy substytucji niem., por. niem. Pollen, z nieetymologicznym $e$ ). Zgodnie z tą interpretacją kraina Polan zaczynała się na Nowotarszczyźnie. Jednoznacznie wskazuje to na małopolski zasięg występowania tego etnonimu. Nie jest to jedyne źródło pozwalające upatrywać zachodniomałopolskiej lokalizacji pierwotnej „Polski”.

W dotychczasowych studiach nad pochodzeniem choronimu Polska zbyt mało uwagi zwracano na jeszcze jeden zabytek. Według Vita sanctorum Andreae seu Zoera(r)di confessoris et Benedicti martyris eremitarum, spisanego przez bł. Maurusa ok. 1064 roku św. Świerad przybył na Węgry „de terra Poloniensium”, tzn. z ziemi polskiej, co potwierdza tzw. „Legenda maior s. Stephani” (Legenda św. Stefana, z ok. 1083 roku), która notuje: „de terra Poliensi”. Według zgodnej opinii badaczy w obydwu wypadkach chodzi o Małopolskę, a ściślej - rejon Dunajca, a więc Małopolskę południową (Pietrzak 1998; 2001). Podobną tradycję przekazuje Jan Długosz (który pierwotną Polskę utożsamiał z Małopolską). Jak wobec tego zapatrywać się na tradycyjną interpretację lokującą „Polan” na Kujawach?

Kwestia w dużej mierze wyjaśnia się dzięki bliższej analizie najwcześniejszych zapisów. Żywot II Brunona (z 1004 roku) jest drugim źródłem potwierdzającym funkcjonowanie formacji etnonimicznej Polanie. Zawiera on wzmiankę o Śląsku jako „Polanicis terris” (części ziem „polskich”, sąsiadującej z Czechami). Jak zauważa Henryk Łowmiański (1989: 116), następuje tu niejako rozszerzenie pojęcia „ziem polskich” na Śląsk. Kolejnym godnym uwagi faktem jest fragment Vita II, 8, gdzie G. Labuda mimochodem zwraca uwagę na rozszerzenie semantyki nazwy Polan sensu largo: pod rokiem 972 następuje konieczność nazwania wojów Mieszka wspólnym określeniem na wzór Teutonów (Labuda 2008: 228). Oczywiste, że obserwujemy tu nominację ex post, a zatem rozszerzenie semantyki nazwy następuje in statu nascendi na użytek narracji literackiej. W tym kontekście 
warto dodać, iż również u kronikarzy saskich znajdujemy tytulatury Miseco dux Poleniorum (977), Miseco Dux Polanorum (985) itp., pochodzą one jednak z kroniki Thietmara, Adama z Bremy i innych z początku XI wieku i stanowią nazewniczy anachronizm (przeniesienie epitetu Chrobrego na jego ojca, tytułowanego zawsze inaczej). Na to, iż Mieszko jako książę ,polański” znany jest wyłącznie z retrospektywnych wzmianek, wskazuje również Paweł Żmudzki (2011). Trzymając się ściśle źródeł historycznych, na temat tła etnopolitycznego początków władzy Mieszka I, można powiedzieć jedynie to, iż jako jeden z synów Siemomysła zarządzał plemieniem Liczkowców, natomiast pierwotne państwo gnieźnieńskie obejmowało swym zasięgiem terytorium plemienne Głobian, nie zaś Polan. Skąd więc owa „nowsza” tytulatura skojarzona wtórnie z pierwszym historycznym władcą Polski?

Odpowiedź na to pytanie wydaje się dość prosta. Obserwujemy mianowicie stopniowe przeniesienie nazwy Polonia (Polania etc.) z jednego z regionów państwa podległego Chrobremu na całe jego królestwo, a Poloni, Polani z mieszkańców tegoż regionu na wszystkich poddanych króla bez względu na ich rzeczywistą identyfikację etniczną (por. przykład Śląska). U Adama z Bremy krańcowy etap tej ewolucji semantycznej daje się obserować niemalże in statu nascendi: w jego Hammaburgensis ecclesiao pontificum (z lat 1075-1088) dorzecze Odry zamieszkują Pomorzanie (łac. Pomerani), natomiast obszar między Prusami, Czechami i Rusią (łac. Pruzzos, Behemos, Ruzzos) zajmuje „Polonia” (łac. regum Polanorum Bolizlao), pokrywa się ona zatem z obszarem niecały wiek wcześniej podległym Gnieznu i Krakowowi.

Wydaje się możliwe, iż pamięć o pierwotnej lokalizacji „Polski” lub „Polska” utrzymywała się dość długo, o czym świadczy jeszcze kronika Jana Długosza. Jego identyfikacja pierwotnej Polski z doliną Dunajca przywodzi na myśl wzmiankę PVL o Polanach, którzy wydzielili się z Lędzan zamieszkujących „kraj nad Wisłą”. Niewykluczone zatem, iż to historycy popełniają błąd, oskarżając Długosza o anachronizm. Opierając się na późnej, literackiego pochodzenia nomenklaturze łac. Polonia, upatrują bowiem w Wielkopolsce pierwotnego desygnatu tej nazwy, podczas gdy bliższa analiza świadczy o możliwości innej lokalizacji zarówno „Polonii”, jak i „Polan” w X w. (małopolskiej).

Z powyższego można wyciągnąć kilka wniosków:

Po pierwsze formacja etnonimiczna Polanie była autentyczną nazwą plemienną. Była to nazwa podrzędna w stosunku do „Lędzanie”, co jest zgodne z treścią PVL i nie stoi w sprzeczności z tzw. Geografem bawarskim, który wspomina o Lędzianach w Małopolsce wschodniej (oraz o Wiślanach w zachodniej). W wymienionych przez niego Wiślanach zasadnie można dopatrywać się Polan - Lędzian osiadłych w dorzeczu Wisły lub konglomeratu Polan oraz innych pomniejszych plemion, określonych tą nazwą zbiorczą derywowaną od hydronimu Wisła ${ }^{1}$. Nie ma uzasadnienia dopatrywanie się w Polanach nazwy nadrzędnej, podrzędnej czy też równorzędnej w stosunku do „Goplan”. Na temat tego etnonimu, odnoszącego się rzekomo do niewielkiego plemienia nad Gopłem, piszę w innym

\footnotetext{
1 Jak wynika z analizy m.in. Geografa Bawarskiego, Alfreda Wielkiego i Konstantyna VII Porfirogenety, dorzecze Wisły zamieszkiwało okresowo kilka plemion, np. do 626 roku Serbowie (przodkowie bałkańskich „Zahumlan”), ok. 845 roku „Wiślanie”, po 890 roku Chorwaci. Według Legendy Panońskiej z ok. 885 roku „w Wiślech” rządził „pogański książę silny wielce”, o nieustalonej atrybucji etnicznej.
} 
miejscu (Łuczyński 2015). Goplanie nad Gopłem to, podobnie jak podbój przez nich Kujaw, Wielkopolski itd., ahistoryczny konstrukt.

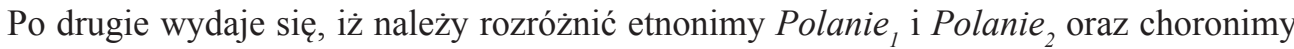
Polska/o Polska/o . Formacje nazewnicze Polanie , Polska/o dotyczą prasłowiańskiej nomenklatury plemiennej i geograficznej - to endoetnonim odtopograficzny odnoszący się do odłamu plemienia Lędzan zamieszkującego pierwotnie Małopolskę i choronim ograniczający się początkowo zapewne do części Małopolski (południowo-zachodniej). Mówiąc o Polanach ${ }_{2}$, Polsce/Polsku, mamy na myśli egzoetnonim i choronim o charakterze literackim, nadane najpewniej przez cudzoziemców na określenie kraju Bolesława Chrobrego i ogółu jego mieszkańców (bez względu na ich samoidentyfikację). W nazwie Polak W znaczeniu egzoetnonimicznym widzieć należy raczej lokalno-terytorialny etnikon moty-

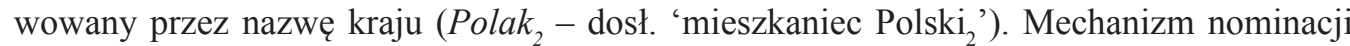
Polanie $_{1} \rightarrow$ Polanie $_{2}$ oraz Polskalo $\rightarrow$ Polskalo $_{2}$ jest przejrzysty i stosunkowo łatwy do rekonstrukcji: było to przeniesienie onimu. Nazwa plemienna została przekształcona w nazwę określającą mieszkańców całego kraju, a nazwa miejscowa - w wywodzącą się od niej nazwę całej krainy - Polska/o poprzez stopniowe rozszerzanie prymarnego znaczenia denotatu.

Etnonim Polanie pod względem formalnym nie budzi wątpliwości: jest to formacja sufiksalna od podstawy psł. *polje + *-janinz, dosł. 'mieszkaniec pól'. Definicje Polan: 'plemię zamieszkujące Wielkopolskę’ (Rospond 1959: 98), 'mieszkańcy urodzajnych pól nadwarciańskich' (Rospond 1984: 298) itp. są błędne. Poprawna to: 'ludzie mieszkający na terenach uprawnych, na polach' lub ogólnie 'ludzie zamieszkujący niziny/teren równinny', natomiast w kwestii lokalizacji jedyną uzasadnioną przez źródła historyczne pierwotną siedzibą wydaje się Małopolska, podobnie jak w wypadku Lędzan.

Wątpliwości budzi za to budowa słowotwórcza i pierwotna postać choronimu. Stanisław Rospond (1959: 52) oraz Małgorzata Sulisz (1971: 265) widzieli tu urzeczownikowiony przymiotnik r. ż. polska (z zestawienia *polska *ziemia), który wtórnie usamodzielnił się w funkcji rzeczownika. Natomiast Kazimierz Hołubowicz (Hołubowicz 1966: 193) uważa, iż jest to urzeczownikowiony przymiotnik r.ż. od nazwy mieszkańców Polanie. Do interpretacji S. Rosponda przychylał się Jerzy Nalepa (1994: 174), z którym polemizuje Maria Karpluk (1994: 183), dostrzegająca w cz. Polska mianownik lp. r. ż. (według deklinacji niezłożonej, podobnie jak w cz. Polsko - mianownik lp. r. n.). Wydaje się to właściwy kierunek interpretacji. Prapolskie *Polbska, *Polbsko (por. np. spol. Ślasko) było najprawdopodobniej właśnie derywatem na *-bska, *-bsko w funkcji dzierżawczej od podstawy imiennej zawierającej segment Pol- (typu Polanie), por. np. głuż. Milsko, Milska (łac. pago Milsca), z tą samą wariantywnością sufiksu nijakiego i żeńskiego. Toponim łużycki pozostawał w związku z etnonimem Milczanie etc., podobnej motywacji nie sposób więc wykluczyć dla pary *Polbska, *Polbsko - *Poljanĕ itd., jednak zagadnienie motywacji wymagałoby bardziej szczegółowego rozważenia. Dość jednak powiedzieć, iż przymiotnik polska i choronim Polska wydają się przypadkowymi homonimami apelatywno-onimicznymi i nie zachodzi między nimi stosunek motywacji nazwotwórczej. Znany współcześnie choronim kontynuuje najpewniej pierwotny toponim *Polbska, który był formacją żeńską z sufiksem -ska, obocznym w stosunku do -sko (częstym w toponimii czeskiej, a także w polskiej, por. *Niżsko $\rightarrow$ Nisko, Drawsko, Drzeńsko, Dębsko, Dulsko, Rajsko i in.). 
Nie ulega wątpliwości, że pierwotny ppol. choronim brzmiał *Polbska lub *Polbsko, jego zlatynizowana wersja została zaś utworzona od etnonimu Poloni za pomocą produktywnego w nazwach grodów, krajów i dzielnic łacińskiego przyrostka -ia (fem. sg., na wzór np. Graecia, Italia, por. Cuyauia, Mazouia, Pomorania, Silesia itp. - Bańkowski 1990: 7). Podstawą derywacji była więc nazwa substytucyjna oddająca ppol. etnikon *Poljanĕ.

Dotychczasowe rozważania każą ponownie rozpatrzyć zarzuconą ponad pół wieku temu hipotezę Henryka Ułaszyna o pierwotnie małopolskiej lokalizacji określenia Polonia (Ułaszyn 1950). Analizując rozwój semantyczny toponimów typu łac. Polonia Minor i Polonia Maior, badacz ten doszedł do wniosku, że pierwsze określenie było starsze, drugie natomiast młodsze, tzn. region mniejszy dał nazwę większemu terytorium, a następnie nazewnictwo miejscowe uległo partykularyzacji. Inaczej mówiąc, zgodnie z tą hipotezą doszło do rozszerzenia nazwy, a następnie jej wtórnego przeniesienia na region sąsiedni. Koncepcję tę Stanisław Urbańczyk określił jako „dość absurdalną”. Argumentował następująco:

„Wszak termin Polonia zanotowany został już około 1000 r., kiedy nie mógł oznaczać nic innego, jak tylko państwo Chrobrego, a więc Wielkopolskę. Dopiero bowiem kilka lat wcześniej stał się Chrobry panem Krakowa; gdyby Polską właściwą była Małopolska, czyż w ciągu kilku lat mogła się nazwa przenieść na całe państwo Chrobrego? Czyż nazwa prowincji podbitej mogła się tak prędko rozszerzyć na całe państwo?” (Urbańczyk 1951a: 141).

S. Urbańczyk bronił tradycyjnej wersji przyjętej w historiografii od czasów Oswalda Balzera, zgodnie z którą choronim Polska (łac. Polonia) od XI-XII wieku odnosił się do Wielkopolski ze stolicą w Gnieźnie, w tym rejonie lokalizującej pierwotnych (,przedmieszkowych") Polan.

W odpowiedzi H. Ułaszyn stwierdzał m.in., że cały ustęp S. Urbańczyka o Polonii ,jest chyba jakimś nieporozumieniem”, podnosząc, iż określenie Polonia odnieść należy do języka literackiego, natomiast pierwotny zasięg nazwy ,polska ziemia” obejmował bliżej nieokreślone terytorium plemienne, umieszczane przez niego jednak w Małopolsce (Ułaszyn 1951: 230). W odpowiedzi S. Urbańczyk jeszcze raz przedstawił swoje stanowisko i powtórzył główne argumenty:

Gdyby Wielkopolska była Polonią wtórną, a Kraków Polonią właściwą, to trudno byłoby zrozumieć, jak nazwa świeżo nabytego terytorium krakowskiego mogła tak szybko przejść na państwowe terytorium w Wielkopolsce

oraz:

Wszystko, co nam przekazały źródła pisane, świadczy, że Polonia to w pierwszym rzędzie sama Wielkopolska, a następnie cała Polska, nigdy zaś sama Małopolska (Urbańczyk 1951b: 232, 233).

W reakcji na dyskusję H. Ułaszyna ze S. Urbańczykiem tradycyjną wykładnię wsparli liczni historycy. Głos zabrał również językoznawca Witold Mańczak, który stwierdzał, że nazwa Polonia etc.:

oznacza pierwotnie krainę położoną w dorzeczu Warty, co do czego nie ma żadnych wątpliwości, i w tym znaczeniu, tj. jako nazwa okolic Poznania, Gniezna i Kalisza, używana jest bez przerwy aż do czasów Długosza, czyli do XV w. (Mańczak 1956: 96). 
Współcześnie lokalizacja Polan na Kujawach ewentualnie w szeroko rozumianej Wielkopolsce jest dominującą hipotezą, powszechnie zaakceptowaną przez większość autorów i obecną w podręcznikach historii (por. np. Zajączkowski 2002: 99; Labuda 2002: 18-22; 2012: 25). Jednak czy słusznie?

Wydaje się, iż należy zwrócić uwagę na podstawowy fakt z dziedziny historii politycznej, który ma wpływ na rozważania semantyczne. Otóż Bolesław Chrobry, czego często nie zauważa się, nie objął państwa Mieszka I na drodze pokojowej (jakoby przejął on władzę nad „Polonią” swojego ojca w drodze dziedziczenia), lecz podbił sąsiednie księstwo po śmierci ojca i przepędził braci (rywali do tronu) oraz Odę. Wraz z Adalbertem i Mieszkiem oraz księżną niemiecką odeszła też znaczna część elity dworskiej stolicy „,ivitas Schinesgne", natomiast sytuację, jaka zaszła, można wyobrazić sobie raczej jako podporządkowanie Gniezna księciu z Krakowa i przeniesienie stolicy do świeżo opanowanego ośrodka władzy, niż podbicie nowej prowincji, której nazwa w niejasny sposób rozszerzyła się na całe państwo, jak zdaje się sugerować S. Urbańczyk. Nastąpiła więc częściowa wymiana elit, a wraz z nią - również zmiana samoidentyfikacji etnicznej dworu książęcego. Bez wątpienia trudno mówić w tym wypadku o ,świeżo nabytym terytorium krakowskim", skoro Chrobry w serii dukatów z lat 1003-1005 tytułował się jako princes Polonie (,książę Polski”), przy czym choronim tu użyty rozumieć należy jako obejmujący połączone tereny civitas Schinesgne i civitas Cracovia, w tym wypadku mamy więc do czynienia

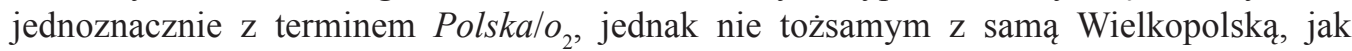
chcieliby to widzieć niektórzy historycy.

W rzeczywistości Wielkopolskę określono jednoznacznie jako Polskę dopiero w XIII wieku, posługując się zlatynizowaną nazwą Polonia, w Rocznikach czeskich. W źródle tym czytamy pod rokiem 968: „Polonia cepit habere episcopum”, jednak wzmianka o założeniu pierwszego biskupstwa w Gnieźnie jest najprawdopodobniej interpolacją kopisty opierającego się na źródle polskim (jak tego przekonująco dowodzi Matla-Kozłowska 2005: 88). Podobnie należy rozumieć zapiskę pod rokiem 1039: „Brethizlaus/Wratizlaus dux vastauit Poloniam...", odnoszącą się do wywiezienia z Gniezna relikwii św. Wojciecha podczas najazdu Brzetysława, jako oddającą literacką terminologię z XII-XIII wieku, nie zaś sytuację nazewniczą w dorzeczu Warty w X - początku XI wieku. Wydaje się zatem, iż jest to jedna $\mathrm{z}$ tych retrospektywnych wzmianek, ponieważ pod rokiem 968 choronim Polonia użyty został w retrospektywie w odniesieniu do czasów Mieszka I, czego dowodzi zestawienie $\mathrm{z}$ toponimem użytym $\mathrm{w}$ Roczniku poznańskim w formie zależnej (łac. Poznaniensis), który został zastąpiony choronimem przez XIII-wiecznego kopistę czeskiego. Formę użytą pod rokiem 1039 należy natomiast rozumieć jako odnoszącą się już do całego państwa Bolesława Chrobrego.

Okazuje się zatem, iż podstawowym błędem, jaki popełniają historycy upatrujący pierwotnej lokalizacji plemienia Polan w Wielkopolsce, jest dokonywanie nieuprawnionej retrospekcji nomenklatury Polonia w znaczeniu Polska/o ${ }_{2}$ na przedpaństwowe Kujawy, podczas gdy wiadomo, iż późniejsza „Polonia Magna” zamieszkiwana była przez Globian, Liczkowców, Milochów, Lubuszan itd., w spisie etnonimów plemiennych na tym terenie brak jednak Polan, których ślady bez trudu odnaleźć można „in Polonia Minor”.

Wydaje się szczególnie warte podkreślenia, iż ślady terminów Polanie ${ }_{1}$ Polska/o w formie derywatów czy toponimów odnajdujemy w źródłach mających pewną wartość etnograficzną, zawierających możliwe reminiscencje tzw. wiedzy potocznej (Vita s. Adal- 
berti, Vita Quinque Fratrum, Vita sanctorum Andreae seu Zoera(r)di confessoris et Benedicti martyris eremitarum, PVL), natomiast nazwy Polanie ${ }_{2}$ oraz Polska/o ${ }_{2}$ notują niemal wyłącznie źródła o charakterze literackim, które dokonują wtórnego przeniesienia lub rozszerzenia nazwy oraz retrospekcji (Vita II, Thietmari Chronicon, Hammaburgensis ecclesiao pontificum, Annales Bohemici i in.). Charakterystyczne, że pierwsza grupa źródeł „Polonię" lokalizuje pośrednio lub bezpośrednio w Małopolsce, druga zaś utożsamia ją z państwem Bolesława Chrobrego, bez względu na historyczną nomenklaturę plemienną, funkcjonującą jeszcze w X wieku. Jak wobec tego należy odnieść się do poglądu, jakoby wszystkie źródła pisane świadczyły o tożsamości Polonia = Wielkopolska, lub do identyfikacji Polonia = okolice Poznania, Gniezna i Kalisza?

W związku z powyższym nasuwa się następujący wniosek: nomenklatura bardziej pierwotna odnosi się do Małopolski zachodniej, natomiast dotychczas dokonywano nieuzasadnionej retrospekcji nazwy na późnym etapie jej rozwoju semantycznego i odnoszono ją do etapu plemiennego na zasadzie projekcji stanu z początku XI wieku na IX-X wiek. Nie ustrzeżono się przy tym etymologii tzw. naiwnej, wywodząc nazwania Polanie i Polskal $\mathrm{O}_{2}$ od wyrazu pospolitego pole (jakoby ich strukturalnym znaczeniem było 'mieszkańcy pól', 'kraj pól' itd.), podczas gdy o motywacji takiej można zasadnie mówić w wypadku form Polanie i ${ }_{1}$ Polskalo ${ }_{1}$ (na gruncie których motywowane są nazwy Pol-anie//-ska ). $_{\text {) }}$.

Podsumowując, pradzieje „Polan gnieźnieńsko-kujawskich”, ich podbój Goplan, walki z Wiślanami etc. można zaliczyć do mitów historiograficznych. Jako historyczne zjawisko polityczne i osadnicze na terenie Kujaw nie są oni poświadczeni przez żadne wiarygodne źródło historyczne, a ich funkcjonowanie w podręcznikach historii opiera się na nieporozumieniu i błędnej etiologii choronimu łac. Polonia. Analiza etnonimu i choronimu uwzględniająca kontekst oraz chronologię pierwszych poświadczeń pozwala na rekonstrukcję etapów rozwoju znaczeniowego tych nazw, pragmatyka źródeł świadczy natomiast, że dość wcześnie ukształtowało się alternatywne wobec historycznych onimów, literackie nazewnictwo używające tych form. Na ich zmiany semantyczne decydujący wpływ miały niewątpliwie „,zamach stanu” dokonany przez Bolesława Chrobrego oraz wejście obu połączonych civitas w etap państwowy, wymagający wprowadzenia jednego wspólnego choronimu i etnonimu. Zapotrzebowanie takie spełniły doskonale nazwy Polska oraz Polanin -Polak.

Ich geneza nie łączyła się jednak z lokalizacją stolicy tak rozumianego nowo tworzonego organizmu państwowego, jak to się tradyjnie przyjmuje. Parafrazując P. Urbańczyka, tak rozumiani Polanie wielkopolscy są istotnie w źródłach nieuchwytni. Ślady toponimu *Polska/o odnoszącego się do Nowotarszczyzny na początku XI wieku oraz epitet *polanbsk Bolesława Chrobrego z ok. 995 roku pozwalają jednak lokalizować to plemię na terenie civitas Cracovia, rządzonego przez sojusznika Sławnikowiców w latach 984-992. Warto w tym kontekście przypomnieć domysł P. Urbańczyka, jakoby określenie Poloni/ Palani/Poleni mogło oznaczać pierwotnie gens Polonorum, czyli jego [księcia] najbliższe otoczenie polityczne. Dwór Chrobrego (w dużej części wywodzący się zapewne z poprzedniego ośrodka politycznego władcy) niewątpliwie mógł być nośnikiem owej „nowej” samoidentyfikacji etnicznej. Spostrzeżenie takie wspiera również pośrednio uwaga Leszka Moczulskiego (2007: 580), że w 992 roku Bolesław Chrobry był nowym władcą, „przybyłym z Krakowa". W tym kontekście bardziej uzasadnione wydaje się przypuszczenie, iż najstarszy z synów Mieszka I do Gniezna przybył już z własną tytulaturą, a czynnikiem 
podtrzymującym nową (państwową) tożsamość była elita wywodząca się częściowo z Małopolski, niż że uzurpator przypisał sobie tytuł poprzedniego władcy (Polaniorum), tym bardziej że brak dowodów na funkcjonowanie takiego w mieszkowej Wielkopolsce. Tak odległe chronologicznie i geograficznie źródła takiego jak PVL i hagiografie św. Wojciecha i św. Świerada są w tej mierze nadzwyczaj zgodne: „Polani” (od których nazwę wzięły Polania i epitet księcia Polaniorum) mogli być w jakiś sposób związani z dorzeczem Wisły. Świadczy o tym autentyczna terminologia toponimiczna i odplemienna, obecna w pierwszych przekazach, jeszcze nie opracowanych literacko. Jest to jeden aspekt owego dość nieoczekiwanego „rozszerzenia” treści znaczeniowej terminu Polanie, Polska itd.

Drugim jest kwestia podnoszona przez krytyków teorii o istnieniu plemienia „Polan” (do których zaliczają się prof. P. Urbańczyk i L. Tapolcai). Etnonim ten wymieniany jest mianowicie początkowo w źródłach o proweniencji czeskiej (hagiografowie św. Wojciecha). Niezasadności poglądu, jakoby Polan czy nazwę Polski wymyślili Czesi, dowiódł przekonująco P. Żmudzki (w druku), nie widać więc potrzeby omawiania tego problemu w tym miejscu. Na uwagę zasługuje jednak pewna interesująca paralela semazjologiczna, na którą naprowadza przykład etnonimu Polanie. Otóż staroruskim określeniem Polaka było, jak wiadomo, srus. Ljach (z psł. *Lęchъ, po denazalizacji na gruncie srus.) będące wariantem augmentatywnym etnonimu *Lęjanin (jak zauważył już Aleksander Brückner). Choć pierwotnie etnonim ten odnosił się do plemienia zamieszkującego pogranicze polsko -ruskie we wczesnym średniowieczu, szybko stał się on zbiorczym określeniem Polaków. Identyczny rozwój znaczeniowy obserwujemy w wypadku etnonimu *Poljaninъ, który upowszechnia się początkowo głównie dzięki środowisku czeskich benedyktynów (Jan Canaparius i inni). Czy historyczny etnonim *Poljanĕ określał pograniczne (czesko-polskie) plemię i w związku z tym był tego typu określeniem co srus. Ljachy, tj. egzoetnonimem, którego ewolucja semantyczna uwarunkowana była przez geograficzną perspektywę sąsiadów?

Ewentualnego rozszerzenia semantycznego etnonimu i deetnonimicznego choronimu nie sposób w tym wypadku wykluczyć. Z pewnością podobnych śladów na tak wczesnym etapie brak w Wielkopolsce, gdzie trudno mówić o jakiejkolwiek historycznej nomenklatu-

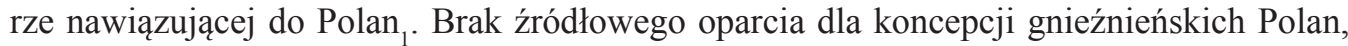
z których pochodzili Piastowie, a przede wszystkim brak tychże wśród plemion ,polskich” u Geografa Bawarskiego oraz trudności w naukowym uzasadnieniu przypisywanej im wybitnej roli w powstawaniu państwa polskiego, polegającej m.in. na podboju "Goplan” (Duczko 2007: 174; Strzelczyk 1987: 65; Tazbir, Kizwalter 1995: 24) dadzą się stosunkowo prosto wyjaśnić. Jerzy Strzelczyk uznaje owych nieobecnych w źródłach Polan wielkopolskich za plemię ,„później najbardziej znane, od którego wywodzić się miała nazwa Polski”.

Wydaje się, iż wszystkie trudności spowodowane są przez przyjęcie a priori nadwarciańskiej lokalizacji Polan, a przede wszystkim przekonanie, iż państwo Mieszka założyli „władcy polańscy”. Tymczasem nie istnieją obiektywne przesłanki, by genezy nazwy Polska szukać nad brzegiem jeziora Gopło. W świetle powyższej analizy początek choronimowi dali bowiem nie Polanie na Kujawach, lecz „podbój” dziedzictwa młodszych braci przez najstarszego syna Mieszka I i spowodowane nim rozszerzenie nazwy dzielnicy podległej początkowo Czechom na nowy twór państwowy, w wyniku którego „Polsko” zaczęło oznaczać całość władztwa siostrzeńca Bolesława II z Przemyślidów.

Na podstawie dokonanej analizy nazwę plemienną *Poljanĕ należy więc uznać za historyczne nomen ethnicum i wiązać z lokalizacją małopolską, podobnie jak *Lędjanĕ, któ- 
ra według PVL stanowiła nazwę nadrzędną względem niej. Należy przede wszystkim wyraźnie podkreślić, że nic nie przemawia za tym, aby nomenklaturze *Poljanĕ, *Visljanĕ odmówić autentyzmu. Wniosek taki jest zgodny zarówno ze źródłami historycznymi, jak i ze stratyfikacją najwcześniej poświadczonych derywatów odetnonimicznych, pozwalającą potwierdzić autentyzm nazewniczy analizowanych powyżej źródeł, a ponadto zlokalizować pierwotne plemię w Małopolsce. Niejasna pozostaje kwestia relacji nazwy do wtórnego odtoponimicznego etnonimu *Visljaně. Wydaje się, iż ta zbiorcza nazwa mogła określać Chorwatów oraz inne pomniejsze plemiona zamieszkujące górny bieg Wisły (w tym np. Polan, których nie ujęto w Geografie Bawarskim osobno). Znajduje to paralelę we wtórnym nazwaniu wschodniosłowiańskich Polan jako Kijan w PVL (zastąpienie pierwotnego etnonimu przez określenie odtoponimiczne, w tym wypadku motywowane na gruncie urbanonimu Kijów 'miasto Polan' etc.).

Mówienie o tak rozumianych „Polanach” jako plemieniu realnie istniejącym w południowo-zachodniej Małopolsce w VIII-X wieku byłoby uzasadnione zarówno z punktu widzenia analizy źródeł historycznych, jak i onomastyki językoznawczej. Przyjęcie hipotezy o małopolskiej praojczyźnie Polan znacząco zmieniłoby wyobrażenia nie tylko o późnoprasłowiańskiej etnonimii, lecz również o etnopolitycznych uwarunkowaniach kształtowania się Państwa Polskiego, a ponadto pozwalałoby w innym niż dotychczas świetle przedstawić genezę takich nazw jak Polska, Polak itp.

\section{Bibliografia}

Bagi D., 2012, Filologia i mitologia. Wegierska ksiązka o historycznych i mitycznych początkach Polski, „Kwartalnik Historyczny” 119 (3), s. 555-565.

Bajer M., Polacy pochodza od Czechów, „Rzeczpospolita” 31 sierpnia - 1 września 2013, http:// www.rp.pl/artykul/1042994,1043084-Polacy-pochodza-od-Czechow.html [dostęp: 08.08.2015]

Bańkowski A., 1990, O wariantywności zapisów nazw własnych w „Kronice Wielkopolskiej”, „Acta Universitatis Lodziensis. Folia Linguistica" 23, s. 5-13.

Duczko W., 2007, Ruś Wikingów. Historia obecności Skandynawów we wczesnośredniowiecznej Europie, przeł. N. Kreczmar, Warszawa.

Hołubowicz K., 1966, Polski 'polny’ w dawnej polszczyźnie na tle ogólnosłowiańskim, w: Studia językoznawcze poświęcone Profesorowi Doktorowi Stanisławowi Rospondowi, red. M. Adamus, Wrocław, s. 193-203.

Karpluk M., 1992, Skąd nazwa Polski i jak brzmi ona w językach naszych słowiańskich sąsiadów, „Język Polski” 72, zesz. 1, s. 4-9.

Karpluk M., 1994, Wyjaśnienia autorki artykulu ,,Skąd nazwa Polski...”, „Język polski” 74, zesz. 3, s. $183-185$.

Labuda G., 2002, Początki państwa polskiego. Pierwsze państwo polskie, Warszawa.

Labuda G., 2008, Trudne początki państwa polskiego w trudnym oświetleniu, „Roczniki Historyczne" 74, s. 209-230.

Labuda G., 2012, Pierwsze wieki monarchii piastowskiej, Poznań.

Lisiecki A., Urbańczyk P., Nie ma dowodów na istnienie Polan, internetowy biuletyn PAP z 8 lutego 2006 r., http://scienceinpoland.pap.pl/aktualnosci/news,22218,nie-ma-dowodow-na-istnienie-polan.html [dostęp: 08.08.2015]

Łuczyński M., 2015, Prapolski etnonim „,Glopeani” (głos w dyskusji), „Slavia Occidentalis” 72/1, s. $121-124$. 
Mańczak W., 1956, Znaczenie nazwy «Polonia Maior», „Zeszyty Naukowe Uniwersytetu Jagiellońskiego, Seria Nauk Społecznych, Filologia” 2, Kraków, s. 95-108.

Mańczak W., 1961, Jeszcze o „Polonia Maior” 'Wielka Polska', „Poradnik Językowy” 2, s. 70-73.

Mańczak M., 2010, Czy cudzoziemcy nadali nazwę Polsce?, „Prace Komisji Nauk Filologicznych Oddziału PAN we Wrocławiu" II, s. 343-357.

Matla-Kozłowska M., 2005, Qui a quo - wzajemne wpływy polskiego i czeskiego rocznikarstwa we wczesnym średniowieczu (X-XI w.), „Acta Universitatis Wratislaviensis” 2783, seria Historia CLXXI, s. 67-89.

Moczulski L., 2007, Narodziny Międzymorza, Warszawa.

Nalepa J., 1994, Polska. Pochodzenie i wiek nazwy, cz. I-II, „Język Polski” 74, zesz.3, s. 174-182; zesz. 4/5, s. 241-245.

Pietrzak S., 1998, Świerad zwany też Zorardem - znad Adriatyku czy Dunajca?, cz. I, „Slavia Antiqua" 39, s. 81-158.

Pietrzak S., 2001, „Terra Poloniensium”, z której pochodzit „Zoerardus-Andreas”, w: Święty Świerad i jego czasy. Materiały z sympozjum naukowego w Tropiu 10-11 lipca 1998, red. S. Pietrzak, Nowy Sącz, s. 158-178.

Rospond S., 1959, Dzieje polszczyzny śląskiej, Katowice.

Rospond S., 1984, Stownik etymologiczny miast i gmin PRL, Wrocław.

Rospond S., 1985, Wiercanie „Geografa bawarskiego” a Polanie = Wielkopolanie, „Slavia Occidentalis" 41, s. 53-56.

Rymut K., 1967, Nazwy miejscowe pótnocnej części dawnego województwa krakowskiego, Wrocław.

Strzelczyk J., 1987, Od Prasłowian do Polaków, Warszawa.

Sulisz M., 1971, Polanin - Polak - Polska, „Język Polski” 51, zesz. 4, s. 264-270.

Tapolcai L., 2009, Polanie - plemię, dynastia, państwo? Skąd się wzięty nazwy: Poloni i Polonia w źródłach zachodnich w końcu X i na poczatku XI wieku?, w: Człowiek w średniowieczu. Między ideologia a historia, Łódź, s. 93-102.

Tapolcai L., 2010, Historyczne i mityczne początki Polski. Kształtowanie się przestrzeni, Budapeszt.

Tazbir J., Kizwalter T., 1995, Polska na przestrzeni wieków, Warszawa.

Tomala L., Językoznawca: nazwa „Polska” oznacza krainę pól, http://naukawpolsce.pap.pl/aktualnosci/news,382297,jezykoznawca-nazwa-polska-oznacza-kraine-pol.html, 31.05 .2011 [dostęp: 08.08.2015]

Ułaszyn H., 1950, Znaczenie nazw Wielkopolska i Małopolska, Łódź.

Ułaszyn H., 1951, Odpowiedź prof. S. Urbańczykowi, „Język Polski” 31, zesz. 5, s. 228-231.

Urbańczyk P., 2006, Kto i kiedy wymyślit Polskę?, „Rzeczpospolita” 8 lutego, s. 16.

Urbańczyk P., 2008, Nie było żadnych Polan, „Gazeta Wyborcza” 24-25 maja, s. 22-23.

Urbańczyk P., 2008, Trudne poczatki Polski, Wrocław.

Urbańczyk P., 2010, Onomastyka a „,sprawa polska”, „Prace Komisji Nauk Filologicznych Oddziału PAN we Wrocławiu" 2, s. 359-364.

Urbańczyk S., 1951a, rec. Ułaszyn 1950, „Język Polski” 31, zesz. 2, s. 140-143.

Urbańczyk S., 1951b, Odpowiedź recenzenta, „Język Polski” 31, zesz. 5, s. 231-233.

Zajączkowski S., 2002, Podziały plemienne Polski w okresie powstania państwa. Geografia plemienna ziem polskich, w: Początki Państwa Polskiego. Księga Tysiąclecia, red. K. Tymieniecki, Poznań, s. 73-109.

Żmudzki P., Kulturowy kontekst nazw „Polanie”, „Polacy”, „Polska” w średniowiecznej historiografii polskiej i ruskiej (w druku) ${ }^{2}$

\footnotetext{
2 Artykuł miał się ukazać pod koniec 2015 roku jako rozszerzona wersja referatu pt. Polanie jako nazwa znaczaca kulturowo, wygłoszonego podczas konferencji Symboliczne i realne podstawy tożsamości społecznej w średniowieczu 29 I 2011 w IH PAN w Warszawie.
} 


\section{MICHAŁ ŁUCZYŃSKI}

\section{More About the Proto-Polish Ethnonym Polanie}

\section{Summary}

The purpose of the article is to review the question of the use of the Proto-Polish ethnonym Polanie. According to the opinion traditionally adopted in historiography, this name referred to one of the tribes inhabiting Greater Poland (the territories of Kuyavia) whose territorial conquests led to the establishment of the Polish State. On the basis of a semantic analysis of the earliest written occurrences of this name, the author develops the thesis that it originally designated a tribe residing in the western part of Lesser Poland, and only at the beginning of the 11th century, again, it came to denote the 'inhabitants of Poland' (understood as the state of Bolesław I the Brave).

Keywords: ethnonymy, toponymy, Pre-Polish tribes, proper names, etymology 
